\title{
Access-site complications of percutaneous diagnostic and therapeutic procedures in coronary artery disease: pseudoaneurysms and arteriovenous fistulas
}

Miejscowe powikłania inwazyjnej diagnostyki i leczenia choroby wieńcowej: tętniaki rzekome i przetoki tętniczo-żylne

\section{Dariusz Karalus, Jarosław D. Kasprzak, Ewa Szymczyk, Jan Z. Peruga, Błażej Michalski, Piotr Lipiec}

Department of Cardiology, Medical University of Lodz, Poland

Postep Kardiol Inter 2012; 8, 4 (30): 280-286 DOI: $10.5114 /$ pwki.2012.31908

\begin{abstract}
Background: Pseudoaneurysms (PAs) and arteriovenous fistulas (AVFs) are among the most serious access-site vascular complications of percutaneous diagnostic and therapeutic procedures in coronary artery disease.

Aim: To assess the clinical course and methods of treatment of these access-site complications.

Material and methods: Medical records of 26949 patients who underwent coronary angiography and/or angioplasty in the period 2000-2009 in two tertiary referral level catheterization laboratories were reviewed. We identified 91 patients with confirmed accesssite complications: 90 iatrogenic PAs and 3 AVFs (2 of which were accompanied by PA).

Results: Prolonged compression with an elastic bandage was the most frequently (55 patients) used first-line treatment of PAs. Others included compression with ultrasound probe (15 patients), ultrasound-guided thrombin injection (11 patients), and surgery (3 patients). Forty-seven patients with PAs required second-line treatment, which in most cases was thrombin injection (23 patients). Thrombin injection and compression with ultrasound probe were the most frequently used third-line treatment techniques. The overall effectiveness (complete closure of PA) of the treatment techniques was: surgery $-100 \%$, thrombin injection $-86.8 \%$, compression with ultrasound probe $-70.8 \%$, prolonged compression with elastic bandage $-42.4 \%$, observation $-0 \%$.

Conclusions: Significant access-site complications of percutaneous coronary interventions, especially AVFs, are infrequent. Spontaneous closure of the PA during hospitalization was not observed. Both thrombin injection and compression with an ultrasound probe allow for fast and effective treatment of iatrogenic PA. However, surgery remains the most effective treatment technique. Prolonged compression with an elastic bandage offers low efficacy.
\end{abstract}

Key words: coronary artery disease, percutaneous coronary intervention, pseudoaneurysm, arteriovenous fistula

\section{Streszczenie}

Wstęp: Tętniaki rzekome (pseudoaneurysms - PAs) i przetoki tętniczo-żylne (arteriovenous fistulas - AVFs) są jednymi z najistotniejszych miejscowych powikłań naczyniowych inwazyjnej diagnostyki i leczenia choroby wieńcowej.

Cel: Ocena przebiegu klinicznego i technik terapii tych miejscowych powikłań.

Materiał i metody: Przeanalizowano dane medyczne 26949 pacjentów poddanych koronarografii i/lub koronaroplastyce w latach 2000-2009 w dwóch pracowniach hemodynamicznych o trzecim stopniu referencyjności. Zidentyfikowano 91 pacjentów z potwierdzonymi analizowanymi powikłaniami miejscowymi: 90 z jatrogennymi PAs i 3 z AVFs (w tym 2 ze wspótistniejącymi z PA).

Wyniki: Przedłużony opatrunek uciskowy był najczęstszą ( 55 pacjentów) techniką leczenia pierwszego rzutu PAs. Do innych metod należały: celowany ucisk sondą ultrasonograficzną (15 pacjentów), przezskórne podanie trombiny do jamy tętniaka (11 pacjentów) i leczenie chirurgiczne (3 pacjentów). Wdrożenia leczenia drugiego rzutu wymagało 47 pacjentów z PAs - najczęściej stosowaną techniką była iniekcja trombiny (23 pacjentów). Podanie trombiny i ucisk sondą ultrasonograficzną były również najczęściej wykorzystywanymi metodami trzeciego rzutu. Skuteczność technik leczenia (całkowite zamknięcie PA) wynosiła: zabieg chirurgiczny - 100\%, podanie trombiny $-86,8 \%$, celowany ucisk sondą ultrasonograficzną $-70,8 \%$, przedłużony opatrunek uciskowy $-42,4 \%$, obserwacja $-0 \%$.

Corresponding author/Adres do korespondencji:

Assoc. Prof. Piotr Lipiec MD, PhD, Department of Cardiology, Medical University of Lodz, 1/5 Kniaziewicza St, 91-347 Lodz, Poland,

tel.: +48 608619 658, e-mail: lipiec@ptkardio.pl

Praca wpłynęła: 25.10.2012, przyjęta do druku: 30.10.2012. 
Wnioski: Istotne miejscowe powikłania inwazyjnej diagnostyki i leczenia choroby wieńcowej występują rzadko, zwłaszcza AVFs. Nie obserwuje się spontanicznego zamykania się jatrogennych PAs w trakcie hospitalizacji. Zarówno podanie trombiny do jamy PA, jak i celowany ucisk sondą ultrasonograficzną pozwalają na szybkie i skuteczne leczenie jatrogennych PAs. Najbardziej skuteczną metodą terapii jest zabieg chirurgiczny. Przedłużony opatrunek uciskowy okazuje się techniką o niskiej efektywności.

Słowa kluczowe: choroba wieńcowa, przezskórna interwencja wieńcowa, tętniak rzekomy, przetoka tętniczo-żylna

\section{Background}

Nowadays coronary angiography and angioplasty are widely applied diagnostic and therapeutic procedures in coronary artery disease. The risk of serious complications related to coronary angiography is $1-2 \%$, with the cumulative risk of death, myocardial infarction or stroke $0.1-0.2 \%$. The risk associated with coronary angioplasty ranges from $0.3 \%$ to $1 \%$ [1]. Major vascular complications, such as retroperitoneal or other bleeding, is estimated at about $0.2-1.7 \%$ after diagnostic catheterization and 1.0-3.1\% after angioplasty [2]. Pseudoaneurysms and arteriovenous fistulas are among the most serious access-site vascular complications [3, 4]. Although the relative incidence of local complications is small, they are becoming a serious clinical issue due to the common use of interventional techniques and increasing number of performed procedures.

\section{Aim}

The aim of this study was to assess the clinical course and methods of treatment of access-site complications (pseudoaneurysms, arteriovenous fistulas) after arterial cannulation in patients undergoing percutaneous diagnostic and therapeutic coronary procedures.

\section{Material and methods}

Medical records of 26949 patients who underwent coronary angiography and/or angioplasty between the years 2000 and 2009 in two departments of interventional cardiology in Lodz (Poland) were reviewed. The centers were tertiary referral level (IIIA and IIIB) catheterization laboratories. In this group 14754 patients underwent coronary angioplasty (balloon angioplasty or stent implantation).

Patients with confirmed access-site complications (pseudoaneurysm or arteriovenous fistula) were identified and their medical history concerning clinical course, laboratory test results, ultrasonographic features and methods of treatment was analyzed.

During the given period access-site vascular complications were observed in 91 patients (42 male, mean age: $63 \pm 9.6$ years; 49 female, mean age: $71 \pm 8.6$ years): 90 iatrogenic pseudoaneurysms and 3 arteriovenous fistulas ( 2 of which were accompanied by pseudoaneurysm).

Forty-one pseudoaneurysms (45.6\%) were the consequence of emergency procedures performed in patients with acute coronary syndrome, 24 (26.7\%) followed urgent procedures in patients with acute coronary syndrome, and 25 (27.8\%) were observed after elective procedures. Two arteriovenous fistulas were the consequence of elective examination, while one followed an emergency procedure.

Fifty-nine pseudoaneurysms (65.6\%) were the result of femoral access (55 of the right, 4 of the left femoral artery), 12 pseudoaneurysms were present after the right radial approach (13.3\%), while 19 pseudoaneurysms were the consequence of right brachial access (21.1\%). Two arteriovenous fistulas were the result of right femoral arterial cannulation and one followed left radial artery access. In the group of patients with pseudoaneurysms, 22 patients had a history of previous coronary angiography. However, none of them had a history of previous pseudoaneurysm.

\section{Statistical analysis}

Continuous variables were initially tested for normality of distribution by the Kolmogorov-Smirnov test. In the case of normal distribution, data are presented as means \pm standard deviation; variables that did not follow normal distribution are presented as medians and upper and lower quartiles. Categorical variables are expressed as percentages. The changes in hemoglobin concentration during the hospitalization period were analyzed using the paired samples $t$-test. The efficacy of treatment methods was compared using the $\chi^{2}$ test. Statistical significance was assumed for $p$ values less than 0.05 .

\section{Results}

Clinical presentation and diagnosis

of access-site vascular complications

In all patients vascular complications were suspected on the basis of clinical symptoms (pain, palpable additional mass, pulsation, vascular murmur) and confirmed by color Doppler ultrasonography (Figs. 1 and 2). Most pseudoaneurysms (77 cases) had one chamber, while 13 pseudoaneurysms were more complex, containing two or more chambers (14.44\%).

In the course of hospitalization the hemoglobin concentration decreased in 61 patients - the mean decrease was $3.8 \pm 2 \mathrm{~g} / \mathrm{dl}$ and reached statistical significance ( $p<0.001)$. Blood transfusion was necessary in 8 patients with pseudoaneurysms (4 femoral and 4 brachial). Each patient received 2 red blood cells units. None of the patients with arteriovenous fistula required blood transfusion. 


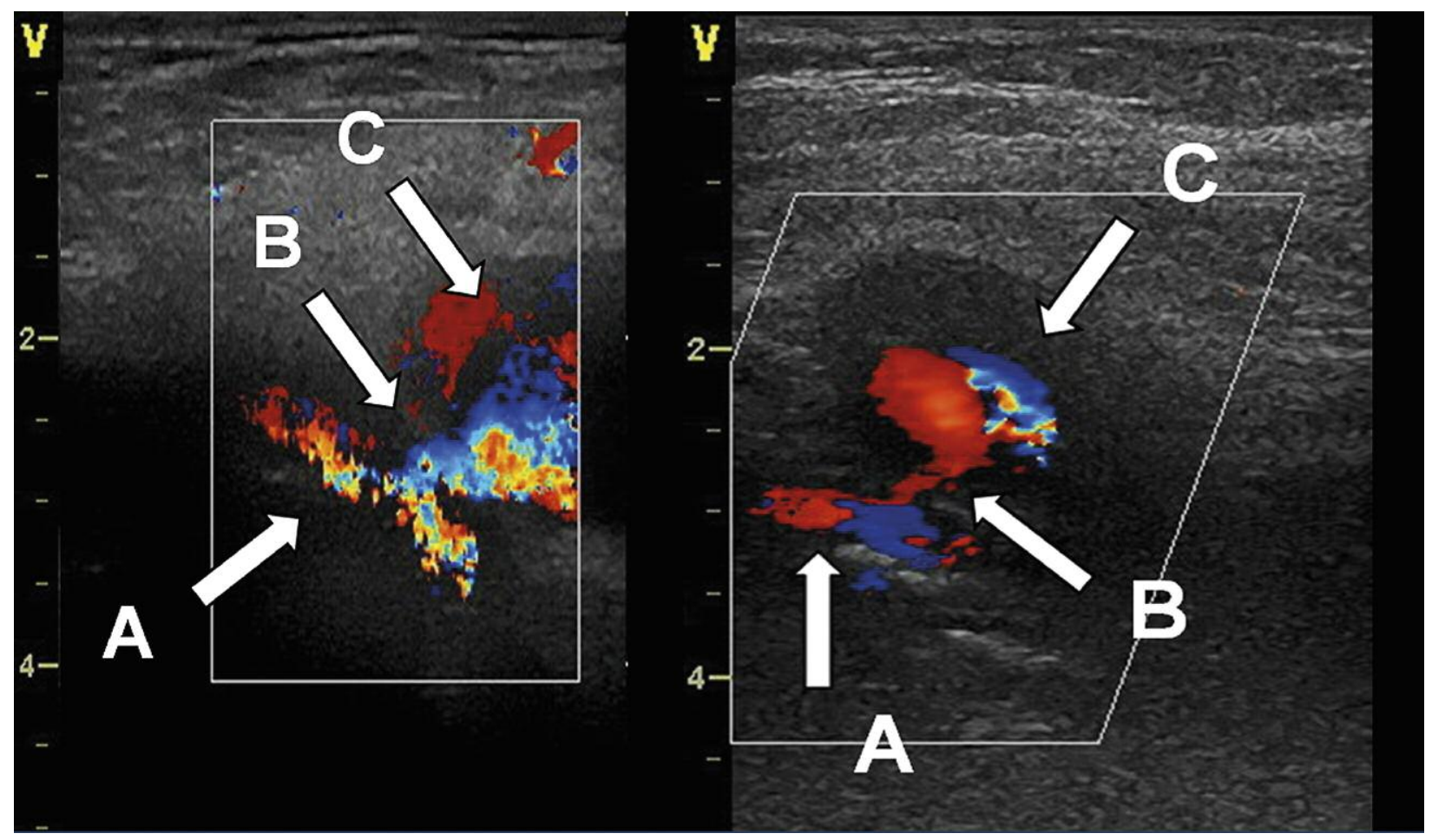

Fig. 1. Two examples of ultrasonographic images of the right femoral artery puncture site demonstrating large iatrogenic pseudoaneurysms

A -femoral artery, B - neck of pseudoaneurysm, C - cavity of pseudoaneurysm

Ryc. 1. Dwa przykłady obrazów ultrasonograficznych miejsc nakłucia prawej tętnicy udowej wykazujących znacznych rozmiarów jatrogenne tętniaki rzekome

A - tętnica udowa, B - szyja tętniaka rzekomego, C - jama tętniaka rzekomego

\section{Treatment of access-site vascular complications}

Prolonged compression with an elastic bandage was the most frequently used first-line treatment of pseudoaneurysms (Table 1 ). Three patients (3.3\%) with pseudoaneurysms were immediately referred for reparative vascular surgery due to their size, significant blood loss and no possibility of other less invasive treatment. Six patients (6.7\%) with pseudoaneurysms remained under observation, with no initial treatment because of the relatively small size of the cavity. In the subgroup of pseudoaneurysms of the radial artery, compression with elastic bandage was used in 8 patients, compression with ultrasound probe in 3 patients and ultrasound-guided thrombin injection in 1 patient. In the subgroup of pseudoaneurysms of the brachial artery, compression with elastic bandage was used in 7 patients, compression with ultrasound probe in 8 patients, surgery was undertaken in 1 patient, whereas 3 patients remained under observation.

The most effective first-line treatment of pseudoaneurysms was surgery $(100 \%$ of cases with complete resolution) and ultrasound-guided thrombin injection (72\%; median dose: $400 \mathrm{U}$; range: 300-800 U). In 3 other patients (27.3\%) treated with thrombin a reduction of pseudoaneurysm size was observed. All methods except for com- pression with an elastic bandage were statistically more efficient than observation $(p<0.05)$. However, the differences between other methods' efficacy did not reach statistical significance ( $p=N S$ ). In summary, the first-line treatment was fully effective in 43 patients (47.8\%).

The most-commonly used second-line treatment was ultrasound-guided thrombin injection (median dose: $400 \mathrm{U}$; range: $200-800 \mathrm{U}$ ). The second-line treatment was fully effective in 37 patients (78.7\%). In 8 patients (17\%) it resulted in a reduction of pseudoaneurysm size, while in 1 patient $(2.1 \%)$ there was no effect observed. One patients had no second-line treatment and was discharged from the hospital because of small size of the pseudoaneurysm. Ultrasound-guided thrombin injection was statistically more effective than compression with an elastic bandage as second-line treatment $(p<0.05)$.

The third-line treatment (Table 3) undertaken in 9 patients resulted in complete closure of the pseudoaneurysm, while 1 patient had no third-line treatment and was discharged.

In 1 patient with femoral pseudoaneurysm after $24 \mathrm{~h}$ of compression with an elastic bandage applied as the firstline treatment, followed by $400 \mathrm{U}$ thrombin injection as the second-line treatment, lower limb ischemia was observed. At first, the patient refused surgery but after two 


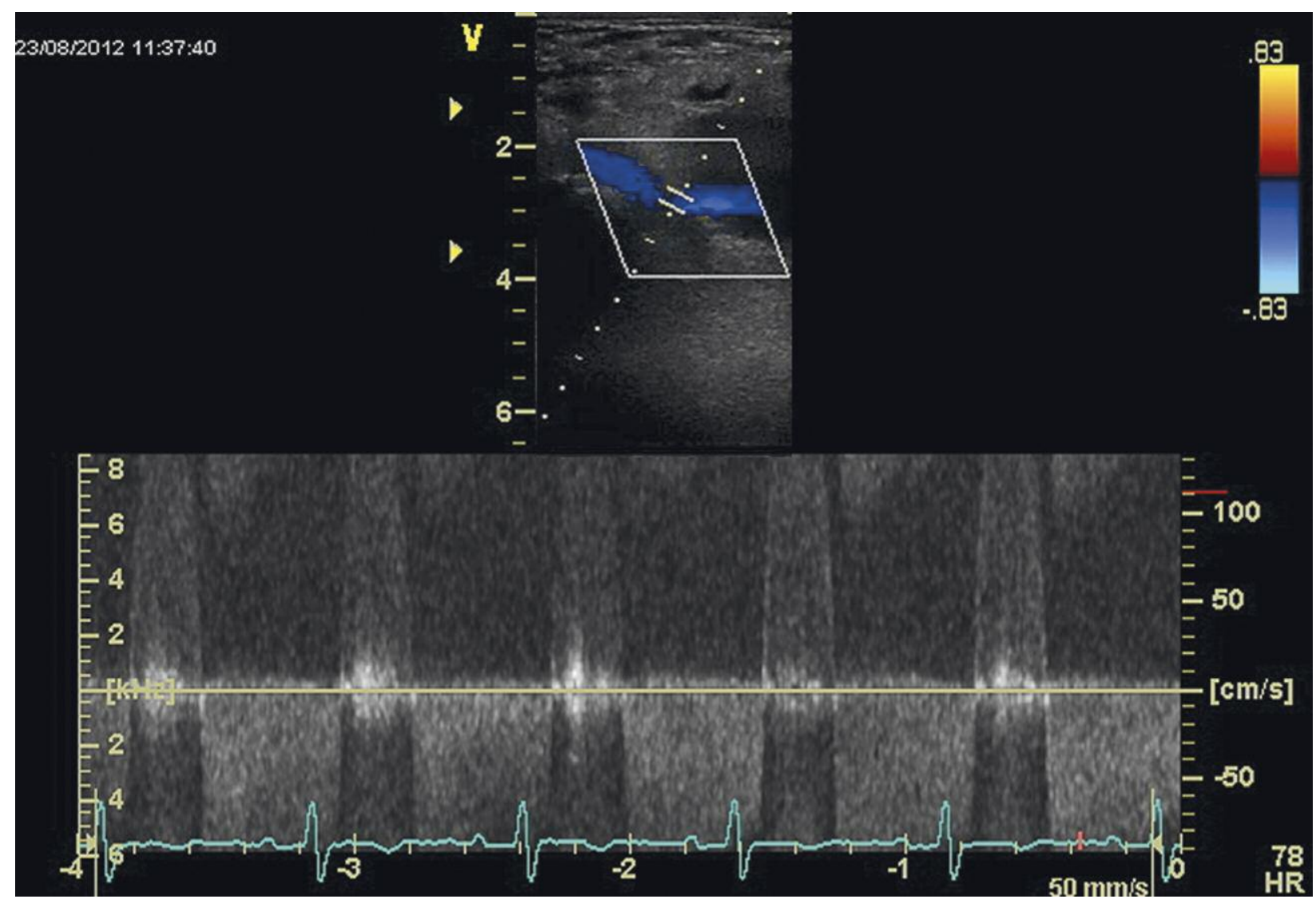

Fig. 2. Bidirectional flow in the neck of the iatrogenic pseudoaneurysm visualized with pulse wave Doppler technique

Ryc. 2. Dwukierunkowy przeptyw w szyi jatrogennego tętniaka rzekomego zarejestrowany technika dopplera fali pulsacyjnej

days she gave her consent for such treatment and was transferred to the department of vascular surgery, where she was operated on.

Based on the above analysis we calculated the overall effectiveness of the treatment techniques and we found that the most effective treatment was surgery (100\% effectiveness in all 10 attempts). The effectiveness of other techniques was as follows: thrombin injection $86.8 \%$, compression with ultrasound probe $-70.8 \%$, prolonged compression with elastic bandage $-42.4 \%$, obser- vation - 0\%. However, the differences in efficacy reached statistical significance only in the following comparisons: surgery vs. prolonged compression with elastic bandage $(p=0.0022)$, surgery vs. observation $(p=0.005)$, thrombin injection vs. prolonged compression with elastic bandage $(p<0.0001)$, thrombin injection vs. observation $(p=0.0001)$, compression with ultrasound probe vs. prolonged compression with elastic bandage $(p=0.032)$, and compression with ultrasound probe vs. observation $(p=0.0076)$.

Table 1. First-line treatment in patients with pseudoaneurysms

Tabela 1. Leczenie pierwszego rzutu u pacjentów z tętniakami rzekomymi

\begin{tabular}{|c|c|c|c|c|c|c|}
\hline Method & $\begin{array}{l}\text { Number } \\
\text { of patients }\end{array}$ & Time & $\begin{array}{l}\text { Complete } \\
\text { resolution }\end{array}$ & $\begin{array}{l}\text { Pseudoaneurysm } \\
\text { size reduction }\end{array}$ & $\begin{array}{l}\text { Pseudoaneurysm } \\
\text { size increase }\end{array}$ & No effect \\
\hline Compression with elastic bandage & $55(61.1 \%)$ & $24 \mathrm{~h}(24 ; 44)$ & $23(41.8 \%)$ & $9(16.4 \%)$ & $5(9.1 \%)$ & $18(32.7 \%)$ \\
\hline Compression with ultrasound probe & $15(16.7 \%)$ & $40 \min (31 ; 58)$ & $9(60 \%)$ & $1(6.7 \%)$ & - & $5(33.3 \%)$ \\
\hline Ultrasound-guided thrombin injection & $11(12.2 \%)$ & - & $8(72.7 \%)$ & $3(27.3 \%)$ & - & - \\
\hline Surgery & $3(3.3 \%)$ & - & $3(100 \%)$ & - & - & - \\
\hline Observation & $6(6.7 \%)$ & 23 h $(21 ; 24)$ & - & - & $2(33.3 \%)$ & $4(66.6 \%)$ \\
\hline
\end{tabular}

Duration is presented as median (lower quartile; upper quartile)

Czas trwania przedstawiony jako mediana (dolny kwartyl; górny kwartyl). 
Table 2. Second-line treatment methods in patients with pseudoaneurysms

Tabela 2. Leczenie drugiego rzutu u pacjentów z tętniakami rzekomymi

\begin{tabular}{|c|c|c|c|c|c|}
\hline Method & $\begin{array}{l}\text { Number } \\
\text { of patients }\end{array}$ & Time & $\begin{array}{l}\text { Complete } \\
\text { resolution }\end{array}$ & $\begin{array}{l}\text { Pseudoaneurysm } \\
\text { size reduction }\end{array}$ & No effect \\
\hline Compression with elastic bandage & $10(21.3 \%)$ & $24 \mathrm{~h}(24 ; 24)$ & $4(40 \%)$ & $5(50 \%)$ & $1(10 \%)$ \\
\hline Compression with ultrasound probe & $6(12.8 \%)$ & $45.8 \pm 29.9 \mathrm{~min}$ & $5(83.3 \%)$ & $1(16.7 \%)$ & - \\
\hline Ultrasound-guided thrombin injection & $23(48 \%)$ & - & $21(91.3 \%)$ & $2(8.7 \%)$ & - \\
\hline Surgery & $6(12.8 \%)$ & - & $6(100 \%)$ & - & - \\
\hline Observation (discharged) & $1(2.1 \%)$ & - & - & - & - \\
\hline Stent & $1(2.1 \%)$ & - & $1(100 \%)$ & - & - \\
\hline
\end{tabular}

Table 3. Third-line treatment methods in patients with pseudoaneurysms

Tabela 3. Leczenie trzeciego rzutu u pacjentów z tętniakami rzekomymi

\begin{tabular}{lcccc} 
Method & Number of patients & Time & Dose & Complete resolution \\
\hline Compression with elastic bandage & $1(10 \%)$ & $24 \mathrm{~h}$ & - & $1(100 \%)$ \\
\hline Compression with ultrasound probe & $3(30 \%)$ & $30 \pm 20 \mathrm{~min}$ & - & $3(100 \%)$ \\
\hline Ultrasound-guided thrombin injection & $4(40 \%)$ & - & $400 \pm 282$ U (200-800) & $4(100 \%)$ \\
\hline Surgery & $1(10 \%)$ & - & - & $1(100 \%)$ \\
\hline Observation (discharged) & $1(10 \%)$ & - & - & - \\
\multicolumn{2}{l}{$\begin{array}{l}\text { Doses and duration are presented as mean } \pm \text { standard deviation (range). } \\
\text { Dawki i czas trwania terapii przedstawione jako średnia } \pm \text { odchylenie standardowe (zakres). }\end{array}$}
\end{tabular}

In the group of patients with arteriovenous fistulas the first-line treatment in two patients was prolonged compression with an elastic bandage (for $24 \mathrm{~h}$ and $48 \mathrm{~h}$ ), whereas the third patient was discharged with a scheduled visit after 10 days, for which he later refused to turn up. Although in one patient compression with an elastic bandage reduced the size of the fistula, he was referred to the department of vascular surgery, where after surgical treatment complete resolution was observed. In the second patient compression with an elastic bandage had no effect, but repeated prolonged ( $24 \mathrm{~h}$ ) compression with an elastic bandage resulted in a decrease of fistula size confirmed on angio-CT. The patient was discharged and remained under ambulatory observation.

\section{Discussion}

The results of our study revealed that local complications of invasive cardiac diagnostics are relatively rare: the incidence of pseudoaneurysms was $0.33 \%$, while arteriovenous fistulas occurred only after $0.01 \%$ procedures. In comparison to other studies concerning mainly femoral access, the incidence of pseudoaneurysms was similar [5] or even less frequent [6-8].

The amount of blood loss and the need of transfusion associated with pseudoaneurysm that were observed in our study were comparable or only slightly larger than in other studies [9]. What is important, all blood transfusions were the consequence of procedures from femoral or brachial, but not radial access.
The diagnosis of local complications was straightforward. Clinical signs and symptoms verified by color Doppler ultrasonography with characteristic two-way flow in the pseudoaneurysm's neck (to its cavity and back) were sufficient for an unequivocal diagnosis. There was no need for use of more advanced diagnostic techniques. Likewise, the presence of an arteriovenous fistula was diagnosed on the basis of clinical signs and use of color Doppler ultrasonography.

As the first-line treatment of pseudoaneurysm prolonged compression with an elastic bandage was the most frequently used method [10]. Its limitation is applying a bandage without certain verification of the pseudoaneurysm's location. Moreover, compression with an elastic bandage should be applied for many hours (at least $24 \mathrm{~h}$ ), which causes significant limitation of the patient's mobility, with a need of complete immobilization in the case of femoral localization of the pseudoaneurysm. This can cause discomfort or even pain and limb ischemia, which is the indication for compression release. Undoubtedly, the main advantage of this method is its wide availability and low cost. However, its efficacy is unsatisfactory; in our study less than half of the patients benefited from prolonged compression with an elastic bandage. What has to be underlined is that obesity, large size and femoral localization of the pseudoaneurysm are negative risk factors for efficacy of this kind of treatment. The evolution of this method is ultrasound-guided compression of the damaged artery using a linear array transducer, 
which is commonly used in vascular ultrasonographic examinations [8]. Continuous visual control eliminates the risk of inappropriate compression (in comparison to an elastic bandage), which favors thrombosis of the pseudoaneurysm. A possible limitation of this method is the patient's and also the operator's discomfort due to long compression of one place. However, in our study ultrasound-guided compression was one of the main treatment methods of pseudoaneurysms due to its minimal invasiveness, wide availability of ultrasonographs and their relatively low operating costs. Similar conclusions were proposed by other authors [11].

In our analysis the efficacy of ultrasound-guided compression was higher than compression with an elastic bandage. However, ultrasound-guided thrombin injection had even higher efficacy, providing complete closure of the pseudoaneurysm. In this technique an ultrasoundguided needle is introduced percutaneously into the cavity of the pseudoaneurysm and thrombin is injected [12-14]. This results in rapid thrombosis of the aneurysm cavity. In our analysis administered doses of thrombin were in the range of 200-800 U. In the 1990s, when this method was introduced into clinical use, doses of injected thrombin were significantly higher (more than $1000 \mathrm{U}$ ), and the potential risk of allergic reactions and distal limb ischemia, due to injection of the thrombin solution into the artery, was also higher. Use of smaller doses of purified thrombin in combination with ultrasound-guided injection significantly reduces the complications mentioned above.

There are also a few recent studies reporting a novel technique of saline injection to obtain pseudoaneurysm obliteration. The technique seems effective, well tolerated, quick, more comfortable for the patient and the doctor, and cheaper than other methods $[15,16]$. However, more trials ought to be done before it is applied as routine clinical practice.

Another alternative noninvasive (minimally invasive) treatment method is the use of special mechanical compression devices, which can be precisely located in a fixed position over the injured artery with a possibility of controlled compression release. The method is comparable to the prolonged freehand compression or ultrasound probe compression, but its main advantage is more comfortable and precise application [6]. Unfortunately in our analysis mechanical compression devices were not used, mainly due to their unavailability in analyzed centers and their relatively high cost in comparison to alternative methods.

The next method is surgical repair of the injured artery in which the pseudoaneurysm is removed and the artery wall is sutured. In our study this method was the last chosen option in most cases, when other methods were ineffective. Only in 3 patients was surgery the first-line treatment due to the size of the pseudoaneurysm, its location and intensive bleeding. The efficacy of surgical repair is almost absolute, but it is an invasive method combined with anesthetic, skin incision, longer healing and convalescence.

For treatment of arteriovenous fistulas analogous methods are available. In our study the most commonly chosen method was prolonged compression with an elastic bandage, the efficacy of which was low. Observation (in the case of a small arteriovenous fistula without significant clinical symptoms) and surgical repair were further treatment methods.

The last method used in our study that can be helpful in treatment of pseudoaneurysms and arteriovenous fistulas is endovascular stent implantation $[17,18]$. This method is effective and safe for the percutaneous closure of pseudoaneurysms and arteriovenous fistulas in femoral localization. However, this promising technique needs further prospective randomized trials which would more carefully delineate the role of this procedure.

We believe that the major limitation of this study is its retrospective character and lack of randomization of patients to various treatment techniques. The selection of treatment method in each patient was based on physicians' choice and other factors such as patient's preferences and techniques' availability. Another limitation is a relatively small number of patients - it has most probably prevented certain differences in techniques' efficacy from reaching statistical significance (e.g. the difference in efficacy between the compression with elastic bandage and observation). We also have no data from long-term followup and therefore can not provide results regarding possible recanalization or spontaneous closure.

\section{Conclusions}

Access-site complications of percutaneous coronary interventions, especially arteriovenous fistulas, are infrequent. However, once diagnosed, they require some form of treatment: spontaneous closure of the pseudoaneurysm during hospitalization was not observed. Both thrombin injection and compression with an ultrasound probe allow for fast and effective treatment of an iatrogenic pseudoaneurysm with sporadic need for surgical bailout and with rare complications. Surgery remains the most effective treatment technique, but should be reserved for large pseudoaneurysms with significant blood loss and cases in which other techniques were ineffective. Prolonged compression with an elastic bandage offers relatively low efficacy.

\section{References}

1. Jolly SS, Yusuf S, Cairns J, et al. Radial versus femoral access for coronary angiography andintervention in patients with acute coronary syndromes(RIVAL): a randomised, parallel group, multicentre trial. Lancet 2011; 377: 1409-1420.

2. Applegate RJ, Sacrinty MT, Kutcher MA, et al. Trends in vascular complications after diagnostic cardiac catheterization and percutaneous coronary intervention via the femoral artery, 1998 to 2007. JACC Cardiovasc Interv 2008; 1: 317-326. 
3. Klocek M, Olszanecka A, Kawecka-Jaszcz K. Wielokomorowy tętniak rzekomy tętnicy udowej niemający kanału - opis przypadku. Post Kardiol Interw 2010; 6: 87-92.

4. Shetty R, Lotun K. Treatment of an iatrogenic femoral artery pseudoaneurysm with concomitant arteriovenous fistula with percutaneous implantation of an amplatzer vascular plug. Catheter Cardiovasc Interv 2012 Mar 16 [Epub ahead of print].

5. Lenartova M, Tak T. latrogenic pseudoaneurysm of femoral artery: case report and literature review. Clin Med Res 2003; 1: 243-247.

6. Chatterjee T, Do DD, Mahler F, Meier B. Pseudoaneurysm of femoral artery after catheterisation: treatment by a mechanical compression device guided by colour Doppler ultrasound. Heart 1998; 79: 502-504.

7. Archbold RA, Robinson NM, Schilling RJ. Radial artery access for coronary angiography and percutaneous coronary intervention. BMJ 2004; 329: 443-446.

8. Tisi PV, Callam MJ. Treatment for femoral pseudoaneurysms. Cochrane Database Syst Rev 2009; 2: CD004981.

9. Knebel AV, Cardoso CO, Correa Rodrigues LH. Safety and feasibility of transulnar cardiac catheterization. Tex Heart Inst J 2008; 35 : 268-272.

10. Lisowska A, Knapp M, Usowicz-Szaryńska M, et al. latrogenic femoral pseudoaneurysms - a simple solution of inconvenient problem? Adv Med Sci 2011; 56: 215-221.

11. Currie P, Turnbull CM, Shaw TR. Pseudoaneurysm of the femoral artery after cardiac catheterisation: diagnosis and treatment by manual compression guided by Doppler colour flow imaging. Br Heart J 1994; 72: 80-84.

12. Krueger K, Zaehringer M, Strohe D, et al. Postcatheterization pseudoaneurysm: results of US-guided percutaneous thrombin injection in 240 patients. Radiology 2005; 236: 1104-1110.

13. Schneider C, Malisius R, Küchler R, et al. A prospective study on ultrasound-guided percutaneous thrombin injection for treatment of iatrogenic post-catheterisation femoral pseudoaneurysms. Int J Cardiol 2009; 131: 356-361.

14. Kłopotowski M, Kukuła K, Mączyńska R, et al. Local ultrasoundguided thrombin injection for treatment of post-catheterization femoral artery pseudoaneurysm - a short term follow-up. Post Kardiol Interw 2009; 5: 129-136.

15. Périard D, Rey Meyer MA, et al. Sealing pseudo-aneurysms of the femoral artery with saline injection: a new technique. Eurolntervention 2012; 7: 1206-1209.

16. Finkelstein A, Bazan S, Halkin A, et al. Treatment of postcatheterization femoral artery pseudo-aneurysm with paraaneurysmal saline injection. Am J Cardiol 2008; 101: 1418-1422.

17. Kouvelos GN, Papas NK, Arnaoutoglou EM, et al. Endovascular repair of profunda femoral artery false aneurysms using covered stents. Vascular 2011; 19: 51-54

18. Thalhammer C, Kirchherr AS, Uhlich F, et al. Postcatheterization pseudoaneurysms and arteriovenous fistulas: repair with percutaneous implantation of endovascular covered stents. Radiology 2000; 214: 127-131. 